\title{
Yacon-based Beverage as Non-dairy Vehicle for Bifidobacterium animalis ssp. lactis: Stability and In vitro Probiotic Viability
}

\author{
Felipe M. F. Watanabe ${ }^{1}$, Caroline Marques ${ }^{1, *} \mathbb{D}$, Fabiane O. Farias ${ }^{1} \mathbb{D}^{\mathbb{D}}$, Luciana N. Ellendersen ${ }^{1} \mathbb{( D )}$, \\ Maria Lucia Masson 1(D) \\ 1 Postgraduate Program of Food Engineering from Federal University of Paraná. Av. Cel. Francisco H. dos Santos, 210, Zip \\ Code 81531-970; felipefarion@hotmail.com (F.M.F.W.); carooolmarques@gmail.com (C.M.); fa.ofarias@gmail.com \\ (F.O.F.); lucianalsn@gmail.com (L.N.E.); masson@ufpr.br (M.L.M.); \\ * Correspondence: carooolmarques@gmail.com;
}

Scopus Author ID 57188685188

Received: 21.11.2020; Revised: 7.12.2020; Accepted: 9.12.2020; Published: 11.12.2020

\begin{abstract}
Probiotics are health-promoting microorganisms commonly applied to functional foods. Dairy products are the most common source of probiotics, which difficult probiotics' consumption by lactose intolerants. In this work, a yacon-based (Smallanthus sonchifolius) beverage was evaluated as a non-dairy vehicle for probiotics (Bifidobacterium animalis ssp. lactis, BB-12®), concerning stability and probiotics viability, during 28 days. $\mathrm{x}$ The yacon-based beverage was properly obtained. To determine the better treatment to stabilize it during storage, combined treatments were optimized via experimental design, and the color stability evaluated the initial changes. The beverage was incubated with the probiotic strain Bifidobacterium animalis ssp. lactis and the fermentation were carried out at $45^{\circ} \mathrm{C}$ and $35{ }^{\circ} \mathrm{C}$ for $10 \mathrm{~h}$ in anaerobic jars. The storage viability was evaluated for 28 days, and the viable cell counting was carried out every seven days. A combination of the immersion of yacon slices into ascorbic acid $0.5 \%(\mathrm{w} / \mathrm{v})$, blanching (3 min), and the addition of $0.4 \%(\mathrm{w} / \mathrm{v}$ ) of ascorbic acid as an antioxidant was the most promising treatment to maintain color stability. Moreover, the fermentation applying $35{ }^{\circ} \mathrm{C}$ maintained the beverage with probiotic status for 14 days. In this work, a probiotic beverage was proposed, with potential health benefits, based on an underused root with great productivity, which will result in a potential low-cost probiotic product compared to dairy-based probiotic beverages.
\end{abstract}

Keywords: fermentation; probiotics; food preservation; food processing; bifidobacteria; beverages.

(C) 2020 by the authors. This article is an open-access article distributed under the terms and conditions of the Creative Commons Attribution (CC BY) license (https://creativecommons.org/licenses/by/4.0/).

\section{Introduction}

The food industry has been investing in functional foods that provide nutrition and improve health and life quality. Among the functional foods classes, it can be mentioned the probiotic, prebiotic, and synbiotic foods. Probiotic food comprises more than $60 \%$ of the functional food market worldwide. It is forecast to reach a market value of $\$ 69.3$ billion by 2023 [1]. Presently, there is an upsurge in the consumption of fruit juices and beverages, especially the functional ones with probiotic bacteria [2-4].

Probiotics are microorganisms that enhance human metabolism when ingested in a sufficient number and colonize the gastrointestinal tract [2]. Some benefits are associated with probiotics as an anti-carcinogenic activity, vitamin production, higher lactose digestion, and 
greater mineral absorption. Moreover, they promote constipation treatment, immune system modulation, lower serum cholesterol level, and protection against intestinal infection [5-8].

Nonetheless, probiotic products are mostly dairy ones [9-11]. Thus, vegetable products as juices are an interesting vehicle for probiotic strains $[4,12]$ since they are lactose and cholesterol free [13], suiting vegan consumers and lactose intolerants [14,15]. The genus Bifidobacterium is one of the main probiotics known, composed of anaerobic species. The strain Bifidobacterium animalis ssp. lactis has a slight oxygen tolerance, granting it a larger usability in the food industry $[10,11,16]$.

Additionally, prebiotics is non-digestible food ingredients or chemically stable structures that modulate gut microbiota. They can reach the bowel where beneficial strains of microorganisms selectively ferment it. The benefits of prebiotics are microbiota modulation, higher calcium, magnesium absorption, anti-carcinogenic activity, superior volume of feces, lower cholesterol, and triglycerides serum levels [17-19].

Inserted in this scenario, there are the yacon (Smallanthus sonchifolius) roots. While most of the plants store starch as a carbohydrate source, the yacon roots store fructooligosaccharides (FOS), which is a prebiotic fiber fermented mainly by bifidobacteria in the human digestive system [17,20], comprising $8 \%$ of sugars (dry matter) in the yacon juice [21]. At the same time, it comprises phenolic compounds and enzymes as polyphenol oxidases (PPO), which makes it susceptible to enzymatic browning [22], promoting nutritional and appearance losses. Thus, the color stability assessment is imperative during its processing. Furthermore, antioxidants' presence as the phenolic structures in yacon roots can enhance anaerobic bacteria's growth [23]. Furthermore, yacon beverages are less explored than flour $[24,25]$, syrup [26, 27], and leaves [28, 29].

Therefore, this work's main purpose was to access the possibility to produce a non-dairy probiotic beverage using the yacon-based beverage, fermented and non-fermented, as a vehicle for Bifidobacterium animalis ssp. lactis (BB-12®). Primarily, evaluating the optimal conditions of color stability from the yacon-based beverage under refrigerated conditions and then comparing the probiotic yacon-based beverage's behavior to the whole milk's viability in the same conditions.

\section{Materials and Methods}

\subsection{Materials.}

The chemicals in analytical grade used in this work were: Ascorbic acid (Neon $\odot$ Commercial, Brazil), De Man, Rogosa and Sharpe (MRS) agar (Merck@, Darmstadt, Germany), cysteine (Sigma-Aldrich ${ }^{\circledR}$, Missouri, EUA) and sodium hydroxide - $\mathrm{NaOH}(\mathrm{Neon} \odot$ Commercial, Brazil).

\subsection{Yacon obtaining.}

The yacon roots were obtained from the local market of Curitiba, Paraná, Brazil. They were kept under refrigeration $\left(7^{\circ} \mathrm{C} \pm 2{ }^{\circ} \mathrm{C}\right)$ until processing and stored for no longer than 7 days. 


\subsection{Yacon-based beverage production.}

For the beverage production, the yacon roots were properly washed, peeled, and cut into slices (around $5 \mathrm{~mm}$ thick). First, the yacon slices were submitted a pre-treatment, described in the next step, to improve the beverage's stability. In the sequence, the slices were processed with water in a proportion of $2: 1(\mathrm{w} / \mathrm{v})$ using a food processor (Britânia $\odot$, Brazil), posteriorly filtering to remove the insoluble solids.

\subsection{Strategies for color stabilization.}

Considering color changes resulting from the rapid oxidation process, which can promote negative visual effects (brown color) on the yacon-based beverage, three treatments were evaluated to achieve strategies to stabilize the beverage's color during storage. For this, a $3^{3}$ complete experimental design was applied as described in Table 1. All experiments were repeated three times, and the analyses performed in triplicate totaling 27 experiments (see Table S1, Supplementary material). The level -1 was considered the absence of that treatment, as it is important to consider treatments' interaction. The levels of ascorbic acid applied were retrieved from the literature $[30,31]$.

Table 1. Color stabilization experimental design, treatments, and levels.

\begin{tabular}{|c|c|c|c|c|}
\hline Treatment & Description & $\operatorname{Exp}$ & desig & \\
\hline \multirow[t]{3}{*}{ 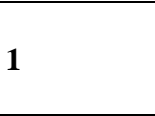 } & \multirow{3}{*}{$\begin{array}{l}\text { Pre-treatment: immersion of yacon slices into an ascorbic } \\
\text { acid solution of different concentrations for } 5 \text { minutes. }\end{array}$} & \multicolumn{3}{|c|}{ Ascorbic acid concentration (wt. \%) } \\
\hline & & -1 & $\mathbf{0}$ & 1 \\
\hline & & 0.0 & 0.5 & 1.0 \\
\hline \multirow{3}{*}{2} & \multirow{3}{*}{$\begin{array}{l}\text { Blanching: exposure of yacon slices to water steam for } \\
\text { different periods }\end{array}$} & \multicolumn{3}{|c|}{ Exposure time (minutes) } \\
\hline & & -1 & $\mathbf{0}$ & 1 \\
\hline & & 0.0 & 3.0 & 6.0 \\
\hline \multirow{3}{*}{3} & \multirow{3}{*}{$\begin{array}{l}\text { Antioxidant addition: ascorbic acid addition directly to the } \\
\text { beverage in different concentrations. }\end{array}$} & Asc & once & vt. \%) \\
\hline & & -1 & $\mathbf{0}$ & 1 \\
\hline & & 0.0 & 0.2 & 0.4 \\
\hline
\end{tabular}

The treatments were evaluated through color measurement using a spectrophotometer Hunterlab Miniscan XE Plus (illuminant D65). The results were based in the $\mathrm{L}^{*} \mathrm{a} * \mathrm{~b}^{*}$ color system where $\mathrm{L}^{*}$ is brightness, (from 0 to 100 ), $\mathrm{a}^{*}$ from -60 (green) to +60 (red) and $\mathrm{b}^{*}$ from -60 (blue) to +60 (yellow). These measurements were made in the fresh beverage and after three days of storage at room temperature $\left(25^{\circ} \mathrm{C}\right)$.

\subsection{Yacon-based beverage fermentation.}

The yacon-based beverage was properly sterilized at $121^{\circ} \mathrm{C}$ for 15 minutes. With the purpose to resuspend the lyophilized bacteria, the probiotic strain Bifidobacterium animalis ssp. lactis (BB-12®, Chr. Hansen, Denmark) was pre-incubated in this sterile yacon-based beverage at $37{ }^{\circ} \mathrm{C}$ for $18 \mathrm{~h}$ under anaerobic conditions, in Erlenmeyer flasks inside anaerobic jars, from lyophilized seed directly added to the beverage $(0.1 \mathrm{~g}$ in $10 \mathrm{~mL})$.

The viable cell count was performed by count-plate using MRS agar supplemented with $0.05 \%$ (w/v) of cysteine. The Petri dishes were kept at $37{ }^{\circ} \mathrm{C}$ under anaerobic conditions for 48 $\mathrm{h}$ [32]. To perform the fermentation, a sample of the pre-incubation media was added to sterile yacon-based beverage enough amount to reach $8 \log \mathrm{CFU} / \mathrm{mL}$ by count-plate, as an initial probiotic concentration in fermentation media [33]. The beverage fermentation was carried out at $45^{\circ} \mathrm{C}$ and $35^{\circ} \mathrm{C}$ for $10 \mathrm{~h}$ in anaerobic jars. 
The $\mathrm{pH}$, titratable acidity, and the viable cell concentration were measured every $2 \mathrm{~h}$. The $\mathrm{pH}$ measurement was performed with the pH-meter Accumet Excel XL25 (AOAC 981.12, 2000). The titratable acidity was measured with a $0.1 \mathrm{M} \mathrm{NaOH}$ solution discounting the initial value. The result was expressed in grams of lactic acid per liter of beverage [35].

Considering that dairy derivatives are the traditional route to probiotic beverages obtaining, in this work, to highlight the applicability of the yacon-based beverage, the same procedures were carried out using UHT milk as a comparison factor (for the UHT milk, the fermentation was carried out only at $45^{\circ} \mathrm{C}$, according to manufacturer specifications).

\subsection{Storage viability.}

Through the experimental design described in Table 1, the best treatments were selected to evaluate the viability of the fermented yacon-based beverage storage. For this, each selected sample was properly stocked in sterile glass flasks at $7{ }^{\circ} \mathrm{C}$ for 28 days. The viable cell counting was carried out every 7 days, and the titratable acidity was measured on the $28^{\text {th }}$ day of storage.

\subsection{Statistical analysis.}

Results were submitted to ANOVA $(\mathrm{p}<0.05)$ and the data expressed as mean \pm standard deviation. Statistical significance obtained for color stability assessment was performed by Tukey and bilateral t-test (both $\mathrm{p}<0.05$ ). Normality, homoscedasticity, ANOVA, and response surface of data were tested through Statistica ${ }^{\circledR} 7.0$ (Tulsa, OK, USA).

\section{Results and Discussion}

\subsection{Color stability.}

A $3^{3}$ experimental design was carried out to determine the optimal treatment to be applied to stabilize the color. Is it known that color changes and browning result in undesirable appearance and among other attributes, color are considered one of the most significant items in a food product evaluation, known to be related to the idea of "healthy food" and "how much to eat of some product" [36] from consumers. Therefore, this step is of great importance to be considered in the development of natural beverages. All $\mathrm{L}^{*} \mathrm{a}^{*} \mathrm{~b}^{*}$ results from experimental design are in Table S2 ( $c f$. Supplementary material). The sample, which received the highest levels of all treatments (Experiment number 27), was considered the control sample. A summary of the most interesting results is in Table 2.

Table 2. Color assessment of yacon-based beverage during $72 \mathrm{~h}$ of refrigerated storage.

\begin{tabular}{|c|c|c|c|c|c|c|c|c|c|c|}
\hline \multirow{2}{*}{ Sample } & \multicolumn{3}{|c|}{ Treatment/Level } & \multicolumn{3}{|c|}{ Day 0} & \multicolumn{3}{|c|}{ Day 3} & \multirow{2}{*}{$\Delta \mathbf{E}^{* *}$} \\
\hline & 1 & 2 & 3 & $\mathbf{L}^{*}$ & $\mathbf{a}^{*}$ & $\mathbf{b}^{*}$ & $\mathbf{L}^{*}$ & $\mathbf{a}^{*}$ & $\mathbf{b}^{*}$ & \\
\hline 4 & -1 & 0 & -1 & $8.68 \pm 1.42^{\mathrm{i}}$ & $-3.87 \pm 0,89^{\mathrm{h}}$ & $4.58 \pm 1.29^{\mathrm{h}}$ & $15.94 \pm 4.74^{\mathrm{i}}$ & $7.97 \pm 1.36^{\mathrm{b}}$ & $14.26 \pm 2.81^{\mathrm{h}}$ & 9.89 \\
\hline 7 & -1 & +1 & -1 & $16.05 \pm 2.41^{\mathrm{h}}$ & $-4.26 \pm 1.88^{\mathrm{h}}$ & $10.41 \pm 2.30^{\mathrm{g}}$ & $17.42 \pm 1.29^{\mathrm{i}}$ & $9.75 \pm 2.88^{\mathrm{a}}$ & $23.00 \pm 4.79^{\mathrm{bcd}}$ & 17.24 \\
\hline 14 & 0 & 0 & 0 & $35.42 \pm 1.40^{\mathrm{a}}$ & $2.41 \pm 0.58^{\mathrm{ef}}$ & $16.30 \pm 1.70^{\text {cdef }}$ & $40.40 \pm 2.31^{\mathrm{ab}}$ & $1.81 \pm 0.82^{\mathrm{c}}$ & $16.57 \pm 1.14^{\mathrm{fgh}}$ & 5.02 \\
\hline 15 & 0 & 0 & +1 & $35.77 \pm 1.42^{\mathrm{a}}$ & $2.44 \pm 0.92^{\mathrm{ef}}$ & $16.73 \pm 1.47^{\text {bcde }}$ & $38.81 \pm 3.01^{\mathrm{abc}}$ & $2.07 \pm 0.99^{c}$ & $15.65 \pm 1.47^{\text {gh }}$ & 3.06 \\
\hline 17 & 0 & +1 & 0 & $35.56 \pm 0.88^{\mathrm{a}}$ & $2.49 \pm 0.63^{\mathrm{ef}}$ & $15.88 \pm 1.58^{\mathrm{def}}$ & $38.89 \pm 2.85^{\mathrm{abc}}$ & $2.65 \pm 0.72^{\mathrm{bc}}$ & $16.24 \pm 0.39^{\mathrm{gh}}$ & 3.36 \\
\hline 23 & +1 & 0 & 0 & $36.18 \pm 0.94^{\mathrm{a}}$ & $2.61 \pm 0.49^{\mathrm{ef}}$ & $17.30 \pm 2.42^{\mathrm{bcd}}$ & $37.99 \pm 1.29^{\mathrm{abcde}}$ & $2.06 \pm 0.74^{\mathrm{c}}$ & $16.88 \pm 2.67^{\text {fgh }}$ & 3.94 \\
\hline 24 & +1 & 0 & +1 & $36.53 \pm 1.55^{\mathrm{a}}$ & $2.57 \pm 0.28^{\mathrm{ef}}$ & $17.63 \pm 2.27^{\mathrm{bdc}}$ & $38.64 \pm 1.62^{\mathrm{abcd}}$ & $2.13 \pm 0.46^{\mathrm{c}}$ & $16.63 \pm 2.53^{\text {fgh }}$ & 3.38 \\
\hline 26 & +1 & +1 & 0 & $35.82 \pm 0.60^{\mathrm{a}}$ & $2.91 \pm 0.65^{\text {cdef }}$ & $16.74 \pm 1.28^{\text {bcde }}$ & $39.88 \pm 0.58^{\mathrm{ab}}$ & $2.55 \pm 0.95^{\mathrm{bc}}$ & $15.75 \pm 1.33^{\text {gh }}$ & 4.20 \\
\hline \multirow[t]{2}{*}{27} & 1 & 1 & 1 & $36.06 \pm 1.04^{\mathrm{a}}$ & $3.03 \pm 0.68^{\text {cdef }}$ & $16.61 \pm 1.39^{b c d}$ & $39.88 \pm 1.76^{\text {abc }}$ & $2.65 \pm 1.15^{b c}$ & $16.35 \pm 1.09^{\text {fgh }}$ & 3.84 \\
\hline & $\begin{array}{l}* \text { Bol } \\
\text { diffe } \\
\text { to }+6\end{array}$ & & (1111 & the Control s & to +60 & . & Ce or coror de & en days $(>3$. & $\begin{array}{l}\text { mean a visible } \\
\text { om -60 (green) }\end{array}$ & \\
\hline
\end{tabular}


The samples submitted only to steam blanching (samples 4 and 7) underwent enzymatic browning right after the beverage extraction. They revealed the lowest $a^{*}$ values $(-3.87 \pm 0.89$ and $-4.26 \pm 1.88)$ values and two of the lowest $L^{*}$ values $(8.68 \pm 1.42 ; 16.05 \pm 2.41)$, indicating the darkest colors among the samples. Besides, there was a significant difference between the initial day and day 3 of analysis in these samples, stating an absence of color stabilization in $72 \mathrm{~h}$ of storage.

Marques and co-workers [37] reported that even after 10 min of steam blanching, 1\% ascorbic acid addition, and $48 \mathrm{~h}$ of refrigerated storage, almost $40 \%$ of the polyphenol oxidase activity from yacon juice remained. Therefore, it can be inferred that a complementary operation should be performed along with blanching to maintain the color stability of yaconbased beverage. According to Neves and silva [38], enzymatic browning is one of the main causes of vegetable quality loss. Yacon rapidly shows this reaction during processing, which is crucial for thermal treatment and antioxidant insertion.

The treatment pairs 14-23, 15-24, 17-26, and 18-27 differ only by the pre-treatment solution's ascorbic acid concentration. When these pairs are individually examined, it was observed that both concentrations of $0.5 \%$ and $1 \%$ ascorbic acid applied did not differ within the pair, inferring that $0.5 \%$ of ascorbic acid concentration in the pre-treatment is satisfactory.

Considering the evaluation of all obtained results, sample 15 was considered the most suitable to be applied in the fermentation step. This sample demonstrated desirable color stability, during all evaluated days, besides the lowest value of $\Delta \mathrm{E}$, using a smaller concentration of ascorbic acid. Also, no significant differences (see Table S2, Supporting Information) were observed between the selected sample and the number 27, which received all treatments' highest level.

For both, fresh beverage or the one after three days of storage, all evaluated variables $\left(\mathrm{L} * \mathrm{a}^{*} \mathrm{~b} *\right.$ ) were statistically significant ( $p$-value $<0.0005, c f$. Table S3 in the Supplementary material), being the $\mathrm{L}^{*}$ color parameter the most affected by the proposed treatments, then it was represented through the response surfaces, as can be observed in Fig. 1.

(A)

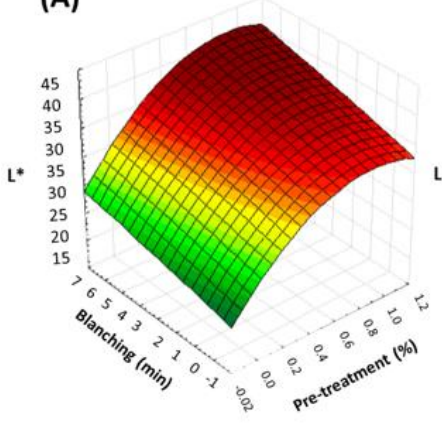

(B)

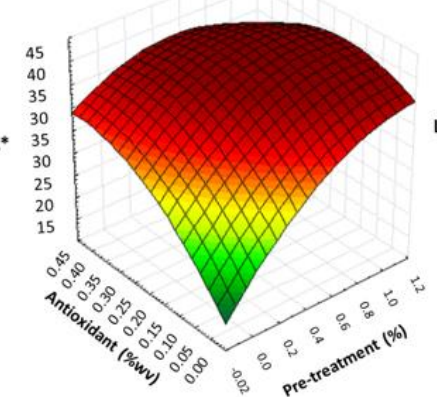

(C)

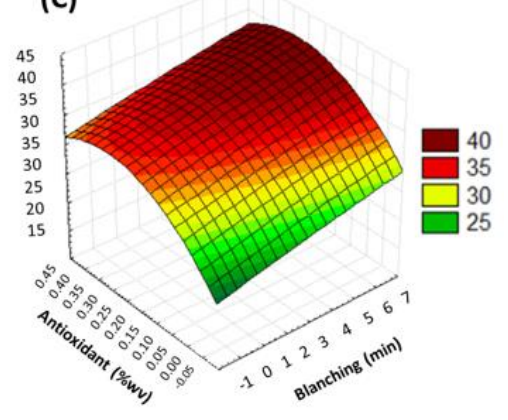

Figure 1. Response surfaces for $\mathrm{L}^{*}$ color parameter considering the combination of the three treatments tested in the refrigerated yacon-based drink (a) Blanching x pre-treatment (b) Antioxidant x pre-treatment and (c) Antioxidant $\mathrm{x}$ blanching.

The response surfaces showed that the highest levels of treatments kept the yacon-based beverage with a lighter color, i.e., with superior $\mathrm{L}^{*}$ values, corroborating the importance of combined treatments to maintain color stability. This fact was expected as the browning defect mainly affects the light-dark parameters in a much more noticeable way since yacon-based beverage without treatments turns dark green. With treatments, it remains yellow [37]. Thus, considering the similarity of results between samples 15 and 27, the optimal conditions for 
yacon-based beverage were: $0.5 \%(\mathrm{w} / \mathrm{v})$ of ascorbic acid in the pre-treatment, $3 \mathrm{~min}$ of steam blanching, and $0.4 \%(\mathrm{w} / \mathrm{v})$ of antioxidant addition.

\subsection{Fermentation parameters and cell viability evaluation.}

The fermentation process evolution was monitored considering the following parameters: $\mathrm{pH}$, acidity changes, and bacterial viability, as shown in Table 3 and Fig. 2a, respectively.

Table 3. $\mathrm{pH}$ and acidity changes during 10 hours of fermentation of yacon-based beverage (at 35 or $45^{\circ} \mathrm{C}$ ) and

UHT milk $\left(45^{\circ} \mathrm{C}\right)$ by BB-12®.

\begin{tabular}{|c|c|c|c|c|c|c|}
\hline \multicolumn{7}{|c|}{ Time of fermentation (hours) } \\
\hline & $\mathbf{0}$ & 2 & 4 & 6 & 8 & 10 \\
\hline \multicolumn{7}{|c|}{ pH measurements } \\
\hline UHT Milk & $6.25 \pm 0.01^{\mathrm{a}}$ & $5.92 \pm 0.02^{b}$ & $5.53 \pm 0.01^{\mathrm{c}}$ & $5.38 \pm 0.03^{\mathrm{c}}$ & $4.90 \pm 0.01^{\mathrm{d}}$ & $4.25 \pm 0.02^{\mathrm{e}}$ \\
\hline Yacon-based beverage $\left(35^{\circ} \mathrm{C}\right)$ & $4.25 \pm 0.01^{\mathrm{a}}$ & $4.25 \pm 0.01^{\mathrm{a}}$ & $4.25 \pm 0.01^{\mathrm{a}}$ & $4.22 \pm 0.01^{\mathrm{a}}$ & $4.23 \pm 0.03^{\mathrm{a}}$ & $4.14 \pm 0.03^{\mathrm{b}}$ \\
\hline Yacon-based beverage $\left(45^{\circ} \mathrm{C}\right)$ & $4.33 \pm 0.04^{\mathrm{a}}$ & $4.31 \pm 0.03^{\mathrm{ab}}$ & $4.28 \pm 0.01^{\mathrm{b}}$ & $4.27 \pm 0.01^{\mathrm{bc}}$ & $4.25 \pm 0.01^{\mathrm{c}}$ & $4.23 \pm 0.01^{\mathrm{d}}$ \\
\hline \multicolumn{7}{|c|}{ Acidity measurements (g of lactic acid/L) } \\
\hline UHT Milk & $0.00 \pm 0.00^{\mathrm{e}}$ & $0.35 \pm 0.06^{\mathrm{e}}$ & $1.00 \pm 0.13^{\mathrm{d}}$ & $1.75 \pm 0.06^{\mathrm{c}}$ & $2.55 \pm 0.06^{\mathrm{b}}$ & $7.05 \pm 0.06^{\mathrm{a}}$ \\
\hline Yacon-based beverage $\left(35^{\circ} \mathrm{C}\right)$ & $0.00 \pm 0.00^{\mathrm{d}}$ & $0.05 \pm 0.06^{\mathrm{cd}}$ & $0.10 \pm 0.01^{\text {bcd }}$ & $0.20 \pm 0.01^{\mathrm{bc}}$ & $0.25 \pm 0.06^{\mathrm{ab}}$ & $0.40 \pm 0.01^{\mathrm{a}}$ \\
\hline Yacon-based beverage $\left(45^{\circ} \mathrm{C}\right)$ & $0.00 \pm 0.00^{\mathrm{d}}$ & $0.01 \pm 0.03^{\mathrm{d}}$ & $0.15 \pm 0.01^{\mathrm{cd}}$ & $0.20 \pm 0.06^{\mathrm{bc}}$ & $0.35 \pm 0.01^{\mathrm{ab}}$ & $0.45 \pm 0.01^{\mathrm{a}}$ \\
\hline
\end{tabular}

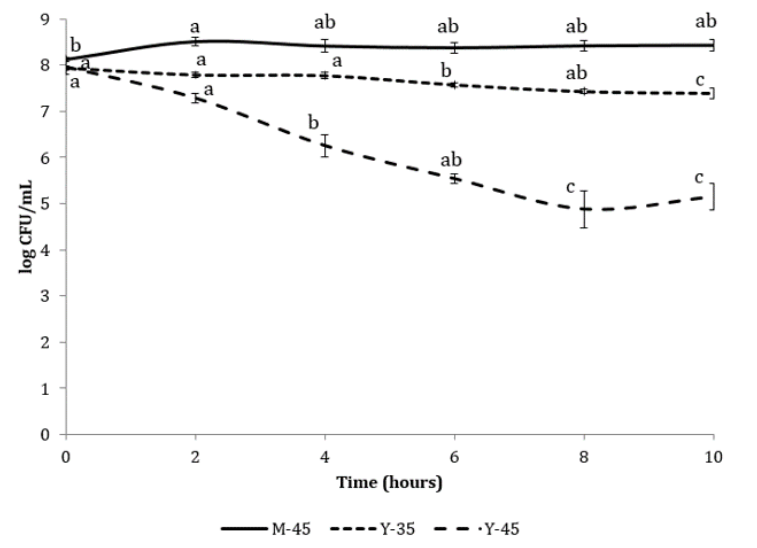

(A)

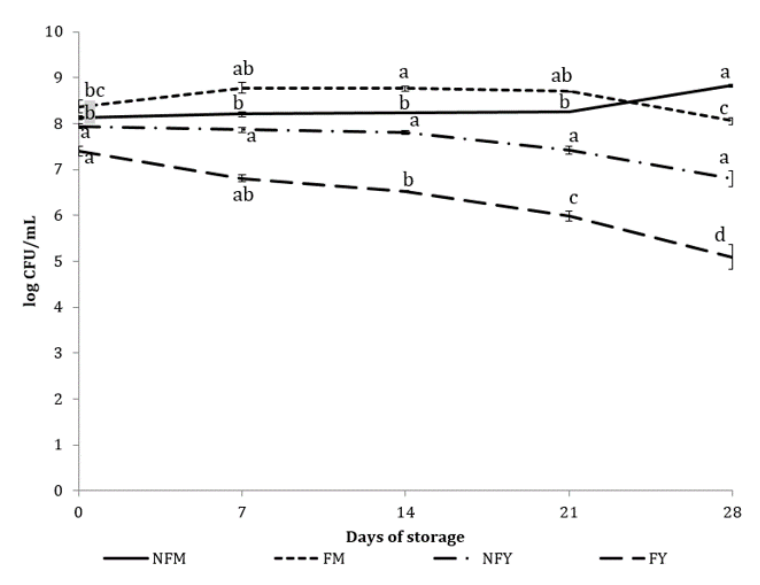

Figure 2. (a) Bacterial viability of Bifidobacterium lactis in milk at $45^{\circ} \mathrm{C}(\mathrm{M}-45)$, yacon-based drink at $35^{\circ} \mathrm{C}(\mathrm{Y}-$ 35 ) and $45^{\circ} \mathrm{C}$ (Y-45); (b) Bifidobacterium viability in non-fermented milk (NFM), fermented milk (FM), NFY (non-fermented yacon-based drink) and fermented (FY) under refrigeration at $7^{\circ} \mathrm{C}$. ANOVA among treatments - Tukey test, different letters in a line mean significant difference $\mathrm{p}<0.05 ;(n=3)$.

Considering the $\mathrm{pH}$ changes, independently of the employed temperature, the yaconbased beverages' $\mathrm{pH}$ had only a slight reduction (around 0.1 ), while, the UHT milk, a more 
meaningful reduction was observed. After $10 \mathrm{~h}$ of fermentation, the UHT milk achieved a $\mathrm{pH}$ value of 4.25 ; in this $\mathrm{pH}$, the casein precipitation and the milk acquire a yogurt characteristic. Similarly, the acidity increment on the UHT milk was more substantial than those observed in the yacon-based beverages.

Both $\mathrm{pH}$ and acidity are directly related to the cell viability in fermented products. According to Saarela and co-authors [39], $\mathrm{pH}$ is one of the most important factors that affect probiotic survival in beverages. Moreover, bifidobacteria are known to be sensitive to $\mathrm{pH}$ values below 4.6.

Is it well-established that probiotic products must contain at least $10^{6}$ or $10^{7} \mathrm{CFU}$ of viable probiotic cells per gram or milliliter of the product to benefit human health [40]. Moreover, dairy products are consolidated as the traditional route to probiotic products obtain, so, as expected, the fermented milk presents a higher amount of viable cell (around $8.28 \mathrm{log}$ $\mathrm{CFU} / \mathrm{mL}$ ). In the yacon-based beverage, in its turn, at $45^{\circ} \mathrm{C}$ as the fermentation temperature, a significant decrease of the viable cell was observed, achieving around $4.99 \log \mathrm{CFU} / \mathrm{mL}$ after $10 \mathrm{~h}$ of the process. On the other hand, when $35{ }^{\circ} \mathrm{C}$ was applied, only a slight reduction occurred, from $7.94 \log \mathrm{CFU} / \mathrm{mL}$ to $7.33 \log \mathrm{CFU} / \mathrm{mL}$ after $10 \mathrm{~h}$ of fermentation, which is a substantial and desirable number of viable cells. The viability cell evaluation suggested $35^{\circ} \mathrm{C}$ as the fermentation temperature most suitable to the purpose of probiotic beverages' obtaining; thus, only the beverage obtained in this temperature was considered in the next steps.

According to Britt [41], acid-food products (with $\mathrm{pH}<4.6$ ) require low temperatures in the process to avoid the destruction of microorganisms, compared to those with a slight acid character $(\mathrm{pH}>4.6)$. This fact corroborates the findings here, where $45{ }^{\circ} \mathrm{C}$ was considered a severe temperature for the yacon-based beverage's fermentation. These results suggested that the acid-character of yacon-based beverage promoted a dependence between the process temperature and the number of BB-12@ viable cells. According to Cronin [16], the Bifidobacterium exhibit great growth in body-temperature (around $37^{\circ} \mathrm{C}$ ), which reinforces the better performance when $35^{\circ} \mathrm{C}$ was applied.

Several authors have reported the successful fermentation of some vegetable-based juices by lactobacilli strains: cashew apple, pomegranate, orange, grape, beet, and cabbage $[3,35,42-45]$. These reinforced the importance of the present findings, establishing a proposal regarding a non-dairy vehicle for probiotics and a valorization route of yacon, a poorly explored root talking about new derivatives.

\subsection{Fermented beverage behavior during storage.}

The obtained fermented beverage was also evaluated considering the acidic behavior, from lactic acid production of the fermentation process, at $35^{\circ} \mathrm{C}$. The refrigerated beverage (fermented and non-fermented) and after 28 days of storage are shown in Table 4. A comparison was performed with fermented and non-fermented milk.

Worth mentioning from Table 4, the lactose seemed to have an important behavior not only on the milk fermentation but also in the non-fermented milk storage, i.e., in both samples, the storage promoted evident acidification due to lactic acid production and consequently, a significant $\mathrm{pH}$ reduction. For the beverage, this behavior was not reported, considering the absence of lactic acid. The yacon-based beverage fermentation results from glucose, FOS, and inulin utilization as a carbon source by BB-12®. According to Rossi and Watson [46,47], $B$. animalis spp. lactis is a glucose/FOS/inulin fermenting-strain with higher growth in glucose and FOS. 
The small changes in the $\mathrm{pH}$ and non-acidity production in the yacon-based beverage, even after 28 days of storage, indicate combined treatments achieve the applied treatment's effectiveness and that good stability. According to the food safety parameters, $\mathrm{pH} 4.6$ is a security limit for non-development of Clostridium botulinum, and recent studies show $\mathrm{pH} 4.2$ is more suitable [48]. Thus, the $\mathrm{pH}$ values found for the 28th day of storage guaranteed that it is important for a refrigerated product. Additionally, the acidity behavior found helped to explain the probiotic viability ahead discussed.

Table 4. Acidity behavior in milk non-fermented, fermented milk $\left(45^{\circ} \mathrm{C} / 10 \mathrm{~h}\right)$ and yacon-based beverage nonfermented and fermented $\left(35^{\circ} \mathrm{C} / 10 \mathrm{~h}\right)$ after 28 days of refrigerated storage.

\begin{tabular}{l|c|c}
\multirow{2}{*}{ Sample } & \multicolumn{2}{c}{ Days of storage } \\
\cline { 2 - 3 } & \multicolumn{1}{c}{$\mathbf{0}$} & $\mathbf{2 8}$ \\
\hline Non-fermented milk & $6.25 \pm 0.01^{* *}$ & $4.56 \pm 0.03^{* *}$ \\
\hline Fermented milk & $4.32 \pm 0.02^{* *}$ & $3.96 \pm 0.06^{* *}$ \\
\hline Non-fermented yacon-based beverage & $4.25 \pm 0.02$ & $4.28 \pm 0.01$ \\
\hline Fermented yacon-based beverage Acidity measurements (g of lactic acid. . L & $4.14 \pm 0.03$ \\
\hline \multicolumn{1}{c}{$0.00 \pm 0.00^{* *}$} \\
\hline Non-fermented milk & $6.35 \pm 0.06^{* *}$ & $6.50 \pm 0.14 * *$ \\
\hline Fermented milk & $0.00 \pm 0.00$ & $13.00 \pm 0.06^{* *}$ \\
\hline Non-fermented yacon-based beverage & $0.40 \pm 0.01$ & $0.00 \pm 0.00$ \\
\hline Fermented yacon-based beverage & $0.80 \pm 0.00^{* *}$
\end{tabular}

\subsection{Probiotics viability in the yacon-based beverage.}

Beyond the physical-chemical properties previously evaluated, to the yacon-based beverage as a probiotic beverage, evaluating the probiotic cells' viability during the storage is essential. These results are reported in Fig. $2 b$.

According to Cronin et al. (2011) [16], the genus Bifidobacterium generally has no significant growth below $20{ }^{\circ} \mathrm{C}$. However, even in the $7{ }^{\circ} \mathrm{C}$ of storage, in the non-fermented milk, the Bifidobacterium grew continuously, reaching a concentration of $8.82 \log \mathrm{CFU} / \mathrm{mL}$. In the fermented milk, the Bifidobacterium developed until the $14^{\text {th }}$ day of storage, followed by a decrease until the $28^{\text {th }}$ day, achieving $8.05 \log \mathrm{CFU} / \mathrm{mL}$ and the milk $\mathrm{pH}$ was 3.96 . In both cases, milk had a satisfying number of viable cells, even after 28 days under refrigeration, as expected for a probiotic product.

Concerning the yacon beverage, the number of viable cells decreased along with the storage for fermented and non-fermented beverages. For the non-fermented yacon-based beverage, the initial concentration of $7.94 \log \mathrm{CFU} / \mathrm{mL}$ decreased to $6.85 \log \mathrm{CFU} / \mathrm{mL}$ after 28 days of storage. However, the fermented yacon-based beverage presented only $5.09 \log$ $\mathrm{CFU} / \mathrm{mL}$. It no longer showed a satisfying number of viable cells after 28 days under refrigeration. Certainly, the heat of the fermentation process affected the beverage more severely than the milk. These results do not disqualify the product proposed here, considering that in 14 days, the fermented beverage presented an adequate number of viable cells (6.52 log $\mathrm{CFU} / \mathrm{mL}$ ), which characterizes it as a probiotic beverage. Also, fresh beverages based on natural products, such as the beverage proposed, are commonly consumed fast.

Combining the concepts, the synbiotic food is the association between probiotic and prebiotic compounds in the same product $[19,49]$, which leverages the functional properties. Thus, for 14 days, the yacon-fermented beverage could be considered a synbiotic beverage in further studies, as yacon roots exhibit FOS and inulin, known prebiotics [50]. A prebiotic evaluation of the fermented beverage must be carried out tough. The yacon roots have high 
yield and productivity, around $10 \mathrm{~kg}$ of roots per plant. However, it is not highly encouraged in most countries [51]. The present findings encourage yacon production, as its derivatives, even the fresh ones, have such potential as healthy functional products.

\section{Conclusions}

In this work, a yacon-based beverage was developed and evaluated as a non-dairy vehicle to probiotic bacteria. Beverage stability and probiotic viability were explored. Firstly, the optimal treatments found to promote a good beverage color stability were: immersion of yacon slices into a $0.5 \%(\mathrm{w} / \mathrm{v})$ ascorbic acid solution for $5 \mathrm{~min}$, followed by $3 \mathrm{~min}$ of steam blanching before beverage extraction; combined with ascorbic acid $0.4 \%(\mathrm{w} / \mathrm{v}$ ) added directly to the beverage. These conditions were able to achieve desirable color stability during $72 \mathrm{~h}$. Considering the probiotic effect, the fermented yacon-based beverage was considered a vehicle for Bifidobacterium for 14 days of storage, with several viable cells of $6.52 \log \mathrm{CFU} / \mathrm{mL}$. The non-fermented yacon-based beverage maintained the probiotic status until day 28 th. The present findings indicated that a yacon-based beverage could be supplemented with Bifidobacterium animalis ssp. lactis, fermented or not, as a non-dairy vehicle to this probiotic strain. Moreover, a probiotic beverage was proposed, with potential health benefits, based on an underused root with great productivity, which will result in a potential low-cost product compared to dairy-based probiotic beverages. Thus, this work showed an effective route to value yacon roots and explored an alternative for small producers to update their yacon production.

\section{Funding}

The authors thank the Coordination for the Improvement of Higher Education Personnel (CAPES), project number 001. F. O. F. acknowledges CAPES and Fundação Araucária for the post-doctoral fellowship (88887.354435/2019-00).

\section{Acknowledgments}

To the National Council for Scientific and Technological Development - CNPq and CAPES for supporting the project. Additionally, the authors thank the Federal University of Paraná (UFPR) for the structure and technical support provided.

\section{Conflicts of Interest}

The authors declare no conflict of interest.

\section{References}

1. Markets \& Markets Probiotics Market by Application (Functional Food \& Beverages [Dairy Products, Nondairy Beverages, Infant Formula, Cereals], Dietary Supplements, Feed), Ingredient (Bacteria, Yeast), Form (Dry, Liquid), End User, and Region - Global Forecast to 2023. Mark. Mark. 2020.

2. Vieira, K.C.d.O.; Da Silva Ferreira, C.; Toso Bueno, E.B.; De Moraes, Y.A.; Campagnolo Gonçalves Toledo, A.C.; Nakagaki, W.R.; Pereira, V.C.; Winkelstroter, L.K. Development and viability of probiotic orange juice supplemented by Pediococcus acidilactici CE51. LWT 2020, 130, https://doi.org/10.1016/j.lwt.2020.109637.

3. Nami, Y.; Lornezhad, G.; Kiani, A.; Abdullah, N.; Haghshenas, B. Alginate-Persian Gum-Prebiotics microencapsulation impacts on the survival rate of Lactococcus lactis ABRIINW-N19 in orange juice. $L W T$ 2020, 124, https://doi.org/10.1016/j.lwt.2020.109190. 
4. Otles, S.; Ozyurt, V.H. Probiotic and Prebiotic Beverages. In: Functional and Medicinal Beverages. Elsevier, 2019; pp. 447-458.

5. Ger, P.; Santivarangkna, C. Advances in Probiotic Technology. CRC Press, 2015.

6. Parussolo, G.; Busatto, R.T.; Schmitt, J.; Pauletto, R.; Schons, P.F.; Ries, E.F. Synbiotic ice cream containing yacon flour and Lactobacillus acidophylus NCFM. LWT - Food Sci. Technol. 2017, 82, 192-198, https://doi.org/10.1016/j.lwt.2017.04.049.

7. Kuerman, M.; Bao, Y.; Guo, Y.; Guo, M. Effects of prebiotic carbohydrates on the growth promotion and cholesterol-lowering abilities of compound probiotics in vitro. LWT 2020, 118, https://doi.org/10.1016/j.lwt.2019.108703.

8. Garg, V.; Kiran; Dhiman, A.; Dutt, R. Anticancer Potential of Functional and Medicinal Beverages. In: Functional and Medicinal Beverages. Elsevier, 2019; pp. 199-234.

9. Bernat, N.; Cháfer, M.; Chiralt, A.; González-Martínez, C. Development of a non-dairy probiotic fermented product based on almond milk and inulin. Food Sci. Technol. Int. 2015, 21, 440-453, https://doi.org/10.1177/1082013214543705.

10. Min, M.; Mason, S.L.; Bennett, G.N.; Hussain, M.A.; Bunt, C.R. Viability assessment of Bifidobacterium longum ATCC 15707 on non-dairy foods using quantitative fluorescence microscopy. J. Microbiol. Methods 2019, 167, https://doi.org/10.1016/j.mimet.2019.105778.

11. Alvarez, M.V.; Bambace, M.F.; Quintana, G.; Gomez-Zavaglia, A.; Moreira, M. del R. Prebiotic-alginate edible coating on fresh-cut apple as a new carrier for probiotic lactobacilli and bifidobacteria. LWT 2020, https://doi.org/10.1016/j.lwt.2020.110483.

12. Mokhtari, S.; Jafari, S.M.; Khomeiri, M. Survival of encapsulated probiotics in pasteurized grape juice and evaluation of their properties during storage. Food Sci. Technol. Int. 2019, 25, 120-129, https://doi.org/10.1177/1082013218801113.

13. Vasudha, S.; Mishra, H. Non dairy probiotic beverages. Int. Food Res. J. 2013, 20, 7-15.

14. Chan, M.Z.A.; Toh, M.; Liu, S.-Q. Growth, survival, and metabolic activities of probiotic Lactobacillus spp. in fermented coffee brews supplemented with glucose and inactivated yeast derivatives. Food Res. Int. 2020, 137, https://doi.org/10.1016/j.foodres.2020.109746.

15. Pimentel, T.C.; Gomes de Oliveira, L.I.; Carvalho de Souza, R.; Magnani, M. Probiotic non-dairy frozen dessert: Technological and sensory aspects and industrial challenges. Trends Food Sci. Technol. 2020, https://doi.org/10.1016/j.tifs.2020.11.008.

16. Cronin, M.; Ventura, M.; Fitzgerald, G.F.; van Sinderen, D. Progress in genomics, metabolism and biotechnology of bifidobacteria. International Journal of Food Microbiology 2011, 149, 4-18, https://doi.org/10.1016/j.ijfoodmicro.2011.01.019.

17. Caetano, B.F.R.; de Moura, N.A.; Almeida, A.P.S.; Dias, M.C.; Sivieri, K.; Barbisan, L.F. Yacon (Smallanthus sonchifolius) as a food supplement: Health-promoting benefits of fructooligosaccharides. Nutrients 2016, 8, https://doi.org/10.3390/nu8070436.

18. Marcon, L.D.N.; de Sousa Moraes, L.F.; Cruz, B.C.d.S.; Teixeira, M.D.d.O.; Vidon Bruno, T.C.; Ribeiro, I.E.; Messias, A.C.; Ferreira, C.L.d.L.F.; de Oliveira, L.L.; Peluzio, M.d.C.G. Yacon (Smallanthus sonchifolius)-based product increases fecal short-chain fatty acids and enhances regulatory $\mathrm{T}$ cells by downregulating ROR $\gamma \mathrm{t}$ in the colon of BALB/c mice. J. Funct. Foods 2019, 55, 333-342, https://doi.org/10.1016/j.jff.2019.02.039.

19. Cruz, B.C.d.S.; Conceição, L.L.d.; Mendes, T.A.d.O.; Ferreira, C.L.d.L.F.; Gonçalves, R.V.; Peluzio, M.d.C.G. Use of the synbiotic VSL\#3 and yacon-based concentrate attenuates intestinal damage and reduces the abundance of Candidatus Saccharimonas in a colitis-associated carcinogenesis model. Food Research International 2020, 137, https://doi.org/10.1016/j.foodres.2020.109721.

20. Kamp, L.; Hartung, J.; Mast, B.; Graeff-Hönninger, S. Plant growth, tuber yield formation and costs of three different propagation methods of yacon (Smallanthus sonchifolius). Ind. Crops Prod. 2019, 132, 1-11, https://doi.org/10.1016/j.indcrop.2019.02.006.

21. Alles, M.J.; Zapata Noreña, C.P.; Tessaro, I.C. Concentration and Purification of Yacon (Smallanthus sonchifolius) Root Fructooligosaccharides Using Membrane Technology. Food Technol. Biotechnol. 2015, 53, https://doi.org/10.17113/ftb.53.02.15.3766.

22. Lago, C.C.; Noreña, C.P.Z. Kinetic and Thermodynamic of Thermal Inactivation of the Peroxidase, Polyphenoloxidase and Inulinase Activities during Blanching of Yacon (Smallanthus sonchifolius) Juice. Food Bioprocess Technol. 2014, 7, 3560-3568, https://doi.org/10.1007/s11947-014-1366-y.

23. Martins, E.M.F.; Ramos, A.M.; Vanzela, E.S.L.; Stringheta, P.C.; de Oliveira Pinto, C.L.; Martins, J.M. Products of vegetable origin: A new alternative for the consumption of probiotic bacteria. Food Res. Int. 2013, 51, 764-770, https://doi.org/10.1016/j.foodres.2013.01.047.

24. Lancetti, R.; Palavecino, P.M.; Bustos, M.C.; León, A.E. Yacon (Smallanthus sonchifolius) flour obtention: Effect of process conditions on quality attributes and its incorporation in gluten-free muffins. LWT 2020, 125, https://doi.org/10.1016/j.lwt.2020.109217.

25. Machado, A.M.; da Silva, N.B.M.; Chaves, J.B.P.; Alfenas, R.d.C.G. Consumption of yacon flour improves body composition and intestinal function in overweight adults: A randomized, double-blind, placebocontrolled clinical trial. Clin. Nutr. ESPEN 2019, 29, 22-29, https://doi.org/10.1016/j.clnesp.2018.12.082. 
26. Adriano, L.S.; Dionísio, A.P.; Abreu, F.A.P. de; Carioca, A.A.F.; Zocolo, G.J.; Wurlitzer, N.J.; Pinto, C. de O.; de Oliveira, A.C.; Sampaio, H.A. de C. Yacon syrup reduces postprandial glycemic response to breakfast: A randomized, crossover, double-blind clinical trial. Food Res. Int. 2019, 126, https://doi.org/10.1016/j.foodres.2019.108682.

27. Adriano, L.S.; Dionísio, A.P.; Pinto de Abreu, F.A.; Wurlitzer, N.J.; Cordeiro de Melo, B.R.; Ferreira Carioca, A.A.; de Carvalho Sampaio, H.A. Acute postprandial effect of yacon syrup ingestion on appetite: A double blind randomized crossover clinical trial. Food Res. Int. 2020, 137, https://doi.org/10.1016/j.foodres.2020.109648.

28. Cruz, P.N.; Lima Reis, P.M.C.; Ferreira, S.R.S.; Masson, M.L.; Corazza, M.L. Encapsulation of yacon (Smallanthus sonchifolius) leaf extract by supercritical fluid extraction of emulsions. J. Supercrit. Fluids 2020, 160, https://doi.org/10.1016/j.supflu.2020.104815.

29. Cruz, P.N.; Fetzer, D.L.; do Amaral, W.; de Andrade, E.F.; Corazza, M.L.; Masson, M.L. Antioxidant activity and fatty acid profile of yacon leaves extracts obtained by supercritical $\mathrm{CO} 2+$ ethanol solvent. $J$. Supercrit. Fluids 2019, 146, 55-64, https://doi.org/10.1016/j.supflu.2019.01.007.

30. Dionísio, A.P.; de Carvalho-Silva, L.B.; Vieira, N.M.; Goes, T. de S.; Wurlitzer, N.J.; Borges, M. de F.; de Brito, E.S.; Ionta, M.; de Figueiredo, R.W. Cashew-apple (Anacardium occidentale L.) and yacon (Smallanthus sonchifolius) functional beverage improve the diabetic state in rats. Food Res. Int. 2015, 77, 171-176, https://doi.org/10.1016/j.foodres.2015.07.020.

31. Vieira, N.M.; Dionisio, A.P.; Goes, T. de S.; Araújo, I.M. da S.; Wilane de Figueiredo, R. Otimização do tratamento ácido do yacon para inativação das polifenoloxidases com manutenção de suas propriedades funcionais. Braz. J. Food Technol. 2018, 21, https://doi.org/10.1590/1981-6723.06316..

32. Capela, P.; Hay, T.K.C.; Shah, N.P. Effect of cryoprotectants, prebiotics and microencapsulation on survival of probiotic organisms in yoghurt and freeze-dried yoghurt. Food Res. Int. 2006, 39, 203-211, https://doi.org/10.1016/j.foodres.2005.07.007.

33. Sheehan, V.M.; Ross, P.; Fitzgerald, G.F. Assessing the acid tolerance and the technological robustness of probiotic cultures for fortification in fruit juices. Innov. Food Sci. Emerg. Technol. 2007, 8, 279-284, https://doi.org/10.1016/j.ifset.2007.01.007.

34. AOAC - Association Of Official Analytical Chemistry. Official Methods of Analysis. 17th ed.; AOAC: Washington, D.C. USA, 2000;

35. Klewicka, E.; Motyl, I.; Libudzisz, Z. Fermentation of beet juice by bacteria of genus Lactobacillus sp. Eur. Food Res. Technol. 2004, 218, 178-183, https://doi.org/10.1007/s00217-003-0830-0.

36. König, L.M.; Renner, B. Colourful = healthy? Exploring meal colour variety and its relation to food consumption. Food Qual. Prefer. 2018, 64, 66-71, https://doi.org/10.1016/j.foodqual.2017.10.011.

37. Marques, C.; Wojeicchowski, J.P.; Cardoso, T.; Mafra, M.R.; Mitterer-Daltoé, M.L.; Masson, M.L. Lactobionic acid as a suitable food preservative for yacon juice. Innov. Food Sci. Emerg. Technol. 2020, 64, https://doi.org/10.1016/j.ifset.2020.102400.

38. Neves, V.A.; Silva, M.A. Polyphenol oxidase from yacon roots (Smallanthus sonchifolius). J. Agric. Food Chem. 2007, 55, 2424-2430, https://doi.org/10.1021/jf063148w.

39. Saarela, M.; Alakomi, H.L.; Mättö, J.; Ahonen, A.M.; Tynkkynen, S. Acid tolerant mutants of Bifidobacterium animalis subsp. lactis with improved stability in fruit juice. LWT - Food Sci. Technol. 2011, 44, 1012-1018, https://doi.org/10.1016/j.lwt.2010.11.004.

40. Shah, N.P. Probiotic Bacteria: Selective Enumeration and Survival in Dairy Foods. J. Dairy Sci. 2000, 83, 894-907, https://doi.org/10.3168/jds.S0022-0302(00)74953-8.

41. Britt, I.J. Thermal processing. In: Food Biodeterioration and Preservation. Tucker, G.S. Ed.; Ames: Blackwell Publishing, 2008; pp. 63-80.

42. Mousavi, Z.E.; Mousavi, S.M.; Razavi, S.H.; Emam-Djomeh, Z.; Kiani, H. Fermentation of pomegranate juice by probiotic lactic acid bacteria. World J. Microbiol. Biotechnol. 2011, 27, 123-128, https://doi.org/10.1007/s11274-010-0436-1.

43. Pereira, A.L.F.; Maciel, T.C.; Rodrigues, S. Probiotic beverage from cashew apple juice fermented with Lactobacillus casei. Food Res. Int. 2011, 44, 1276-1283, https://doi.org/10.1016/j.foodres.2010.11.035.

44. Yoon, K.Y.; Woodams, E.E.; Hang, Y.D. Fermentation of beet juice by beneficial lactic acid bacteria. $L W T$ - Food Sci. Technol. 2005, 38, 73-75, https://doi.org/10.1016/j.lwt.2004.04.008.

45. Yoon, K.Y.; Woodams, E.E.; Hang, Y.D. Production of probiotic cabbage juice by lactic acid bacteria. Bioresour. Technol. 2006, 97, 1427-1430, https://doi.org/10.1016/j.biortech.2005.06.018.

46. Rossi, M.; Corradini, C.; Amaretti, A.; Nicolini, M.; Pompei, A.; Zanoni, S.; Matteuzzi, D. Fermentation of Fructooligosaccharides and Inulin by Bifidobacteria: a Comparative Study of Pure and Fecal Cultures. Appl. Environ. Microbiol. 2005, 71, 6150-6158, https://doi.org/10.1128/AEM.71.10.6150-6158.2005.

47. Watson, D.; O’Connell Motherway, M.; Schoterman, M.H.C.; van Neerven, R.J.J.; Nauta, A.; van Sinderen, D. Selective carbohydrate utilization by lactobacilli and bifidobacteria. J. Appl. Microbiol. 2013, 114, 11321146.

48. Mohammad, Z.H.; Payton, L.; Sirsat, S.A. Efficacy of sushi rice acidification: Quantification of Bacillus cereus and Clostridium perfringens during simulation of retail practices. LWT 2020, 131, https://doi.org/10.1016/j.lwt.2020.109884. 
49. Khaneghah, A.M. Probiotics and Prebiotics as Functional Foods: State of Art. Agri Res Tech Open Access 2018, 13, 1-12, https://doi.org/10.2174/1573401314666180416120241.

50. Campos, D.; Betalleluz-Pallardel, I.; Chirinos, R.; Aguilar-Galvez, A.; Noratto, G.; Pedreschi, R. Prebiotic effects of yacon (Smallanthus sonchifolius Poepp. \& Endl), a source of fructooligosaccharides and phenolic compounds with antioxidant activity. Food Chem. 2012, 135, 1592-1599, https://doi.org/10.1016/j.foodchem.2012.05.088.

51. Ojansivu, I.; Ferreira, C.L.; Salminen, S. Yacon, a new source of prebiotic oligosaccharides with a history of safe use. Trends Food Sci. Technol. 2011, 22, 40-46, https://doi.org/10.1016/j.tifs.2010.11.005. 


\section{Supplementary files}

Table S1. Complete $3^{3}$ experimental design to access yacon juice color stabilization

\begin{tabular}{|c|c|c|c|}
\hline Samples & $\begin{array}{c}\text { Pre-treatment solution } \\
\text { concentration }\end{array}$ & Blanching Period & Antioxidant Addition \\
\hline 1 & -1 & -1 & -1 \\
\hline 2 & -1 & -1 & 0 \\
\hline 3 & -1 & -1 & +1 \\
\hline 4 & -1 & 0 & -1 \\
\hline 5 & -1 & 0 & 0 \\
\hline 6 & -1 & 0 & +1 \\
\hline 7 & -1 & +1 & -1 \\
\hline 8 & -1 & +1 & 0 \\
\hline 9 & -1 & +1 & +1 \\
\hline 10 & 0 & -1 & -1 \\
\hline 11 & 0 & -1 & 0 \\
\hline 12 & 0 & -1 & +1 \\
\hline 13 & 0 & 0 & -1 \\
\hline 14 & 0 & 0 & 0 \\
\hline 15 & 0 & 0 & +1 \\
\hline 16 & 0 & +1 & -1 \\
\hline 17 & 0 & +1 & 0 \\
\hline 18 & 0 & +1 & +1 \\
\hline 19 & +1 & -1 & -1 \\
\hline 20 & +1 & -1 & 0 \\
\hline 21 & +1 & -1 & +1 \\
\hline 22 & +1 & 0 & -1 \\
\hline 23 & +1 & 0 & 0 \\
\hline 24 & +1 & 0 & +1 \\
\hline 25 & +1 & +1 & -1 \\
\hline 26 & +1 & +1 & 0 \\
\hline 27 & +1 & +1 & +1 \\
\hline
\end{tabular}




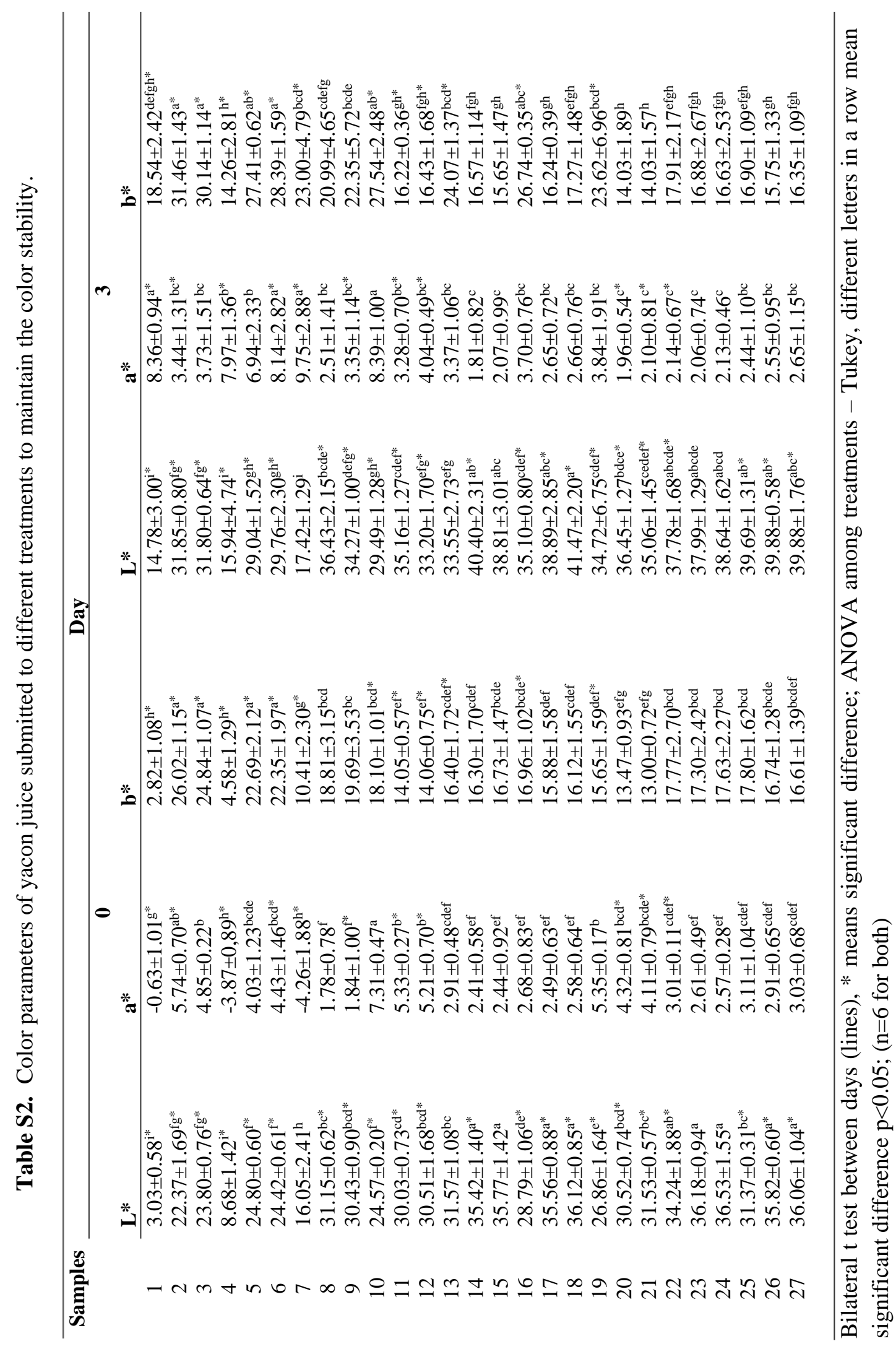


Table S3. Effect of the color variables in the yacon juice color stability during $72 \mathrm{~h}$,

\begin{tabular}{ccccc}
\hline & & \multicolumn{3}{c}{ p value } \\
\hline Day & Parameter & Pre-treatment & Blanching & Antioxidant \\
\hline Initial & $\mathrm{L}^{*}$ & 0.0000146 & 0.0105993 & 0.0008629 \\
& $\mathrm{a}^{*}$ & 0.0693528 & 0.0095296 & 0.0989389 \\
& $\mathrm{~b}^{*}$ & 0.7681859 & 0.7409568 & 0.0652577 \\
\hline $\mathbf{3}$ & $\mathrm{L}^{*}$ & 0.0000410 & 0.0324438 & 0.0019347 \\
& $\mathrm{a}^{*}$ & 0.0002842 & 0.3718384 & 0.0189736 \\
& $\mathrm{~b}^{*}$ & 0.0050592 & 0.3494670 & 0.5305747
\end{tabular}

Values $<0.05$ mean significant difference (ANOVA; Tukey test). 